\title{
Blockchain technology for sustainable supply chains of agri-food in Vietnam: a SWOT analysis
}

\author{
Thien Vu Tran ${ }^{1, *}$, Hue Hong Hoang Trinh ${ }^{2}$
}

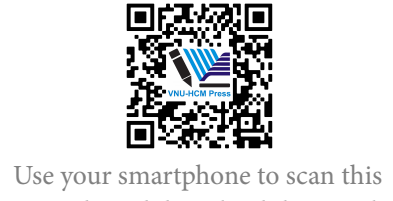

QR code and download this article
${ }^{1}$ Vietnam-Korea University of Information and Communication Technology, The University of Da Nang, Vietnam

${ }^{2}$ University of Economics and Law, VNU HCMC, Vietnam

\section{Correspondence}

Thien Vu Tran, Vietnam-Korea University of Information and Communication Technology, The University of Da Nang, Vietnam

Email: ttvu@vku.udn.vn

History

- Received: 28/07/2020

- Accepted: 21/12/2020

- Published: 13/2/2021

DOI : 10.32508/stdjelm.v5i1.675

\section{Check for updates}

\section{Copyright}

( ) VNU-HCM Press. This is an openaccess article distributed under the terms of the Creative Commons Attribution 4.0 International license.

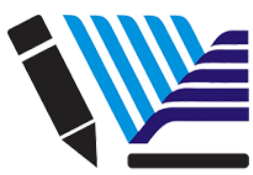

VNU-HCM Press

\begin{abstract}
Such a disruptive technology as the blockchain platform has a potential to provide value-added contributions towards multiple-disciplinary applications these days. Blockchain technology, considered as the second generation of the Internet in the digital age, has been applied in practice for various industry such as finance, healthcare, tourism, retailing, manufacturing, education, public sector, supply chains management, agri-food industry and so on. In which, supply chain operations, particularly agri-food management, becomes a prosperous beneficiary from blockchain technology. In the local context, Vietnam has been achieved the competitive advantages in agricultural production among the world in some agri-food products such as black peppercorn, cashew nuts, coffee, coconut, rice, and rubber. Furthermore, Vietnam is considered as one of pioneers in implementing blockchain technology for traceability and transparency of agri-food products across Association of South East Asian Nations (ASEAN) countries. However, design and implementation of the blockchain technology application in agri-food production in the case of Vietnam agriculture industry have been confronted with opportunities and challenges, besides its strengths and weaknesses in nature. This paper aims to concentrating on the analysis of Strengths, Weakness, Opportunities and Threats (SWOT) of blockchain-applied supply chain relevant to agri-food products. In addition, the application of blockchain technology in supply chains has been expected to promote the sustainable development of Vietnam agriculture, in the accordance with the United Nation Sustainable Development Goals (SDGs) in the $21^{\text {st }}$ century. We adopt the research method of interpretive approach to synthesize the literature and reasonably induce research conclusions. We finally prescribe some policy recommendations and implications for agri-food stakeholders such as regional policy makers, agri-food based blockchain platform designers, executives, and farmers as users in relevant to facilitate the blockchain technology for agri-food chains in Vietnam agriculture. Key words: Blockchain technology, supply chain management, sustainability, Vietnam agriculture, SWOT analysis
\end{abstract}

\section{INTRODUCTION}

In recent years, globalization along with the volatility of weather conditions are dictating the increasing demands for high quality, value-added, and customized agri-food products. Responding to the consumer's lifestyle trends, supply chains within the agrifood sector has been designed, developed, and operated efficiently and robustly. Supply chain management is a key concept for its competitiveness in the agri-food industry. Accordingly, an agri-food supply chain management is comprised of a set of activities "from a farm to fork" sequence including planting, growing, farming, harvesting, processing, delivering, retailing, and consuming ${ }^{1}$.

The traditional agri-food supply chains have exposure to some drawbacks of partnership. First, it is timeconsuming to trace and track agri-food products because most of the information about these products is shared among supply chain actors in paper-based documents or even if these actors use the internal enterprise information systems such ERP (Enterprise Resource Planning) platform. In general, the body of literature shows that the traditional agri-food supply chains particularly represent problems of information asymmetry $^{2-5}$, also known as "information failure", where can create an imbalance of power in transactions along the supply chain until the final consumer. In this case, suppliers seem to have more or better information concerning food safety and food quality than customers. In other words, information for agricultural products has a tendency to be silo and inter-dependent, and external interoperability across supply chains is limited. Because of the lack of information in the transactions, customers or users may consume a lot of time to trace and track information about products and vendors.

Second, the agreement among stakeholders in supply chains faces difficulties due to various partners such as 
farmers, suppliers, merchants, transporters, custom, institutional finance, and customers getting involved in the chain from farm to fork. Any changes in demands certainly magnify big changes in supplies, so call bullwhip effects. Third, all partners face harder in control food safety and security because of blur visibility of information flow across the supply chains. Even though Vietnam authorities support to voluntarily adopt the good standards such as Vietnam Good Agricultural Practice (VietGAP), and Hazard Analysis and Critical Control Point (HACCP), consumers are still concerned with the contaminated food that influences to consumers' health conditions ${ }^{6}$.

Blockchain technology - distributed ledger technology - has changed our approach to share and transact data. As a matter of fact, blockchain technology, considered as the second generation of the Internet, provides 'the Internet of Value', whereas recent decades have witnessed the ceaseless evolution of the first generation of the Internet also named at 'the Internet of Information'. Therefore, blockchain technology is applied in a wide range of industries such as healthcare, education, tourism, retail, pharmaceutical industry, public sector, finance, and supply chain. Among these, blockchain platform seems to be potentially suitable to supply chain management. This is because most salient features of blockchain are distributed architecture in the peer-to-peer network, immutability of data - impossible to tamper with as soon as transactional approval, and transacted without the intermediaries ${ }^{7-9}$. The blockchain technology promises to provide the transparency among supply chain agents, traceability of food products, and make the supply networks visible ${ }^{8}$. It is subsequently argued that blockchain are befitting with supply chain operations and management.

Vietnamese agriculture is at the crossroad ${ }^{10}$. Since the 'Doi Moi'(Renovation) reform in 1986, Vietnam agriculture sector has achieved enormous progress, particularly enhancing the performance, increasing agricultural yields, and exportation of agri-food abroad. Besides these achievements, this sector needs to consider the improvement of not only quantitative output but also the quality of products for the purpose of efficiency and effectiveness gains ${ }^{10}$. In other words, Vietnam agriculture sector might seek to "do more with less" and reach sustainable agricultural productivity and growth ${ }^{10}$.

In the wake of advanced technology, agriculture sector seems to be beneficiary from these advances for higher agriculture higher productivity and growth. Among these, blockchain in align with the Internet of Things, sensors, mobile network infrastructure can attribute to the productivity of agriculture sector in general and agri-food supply chains in particular. There is thus a convergence between agriculture and Information and Communication Technology (ICT) in our modern world. In Vietnam, ICT enterprises have had the proof of concept in blockchain platforms since mid-2018 and some initiatives in relevant to tracing agri-foods have implemented blockchain in reality such as wowtrace, fruitchain, agridential ${ }^{11}$ mostly appearing in the South of Vietnam (i.e, Mekong Delta, Central Highland).

However, the literature on blockchain-based supply chains for the agri-food industry in Vietnam so far seems scare to our best knowledge. This study is an initial effort to synthesize the state-of-art literature of blockchain-based supply chains in Vietnam through an approach that we apply a SWOT analysis to identify internal and external factors for Vietnamese agri-food supply chain management. On this basis, we propose the mutual effects of blockchain on sustainable development.

We outline this paper into five sections. The first introduces the blockchain in agri-food supply chain management in Vietnam. The next section provides the literature on blockchain, agri-food supply chains, and state-of-the-art Vietnam agriculture. Third, we present the SWOT analysis method. The fourth discusses on SWOT analysis, the benefits and drawbacks, the association between blockchain and sustainability. We briefly conclude the research and offer some policy implications for relevant stakeholders.

\section{LITERATURE REVIEW}

The United Nations (UN) organization acclaims the 2030 agenda for sustainable development goals, which is a plan of actions for people, planet, and prosperity. Three dimensions of sustainable development are the economic, social, and environmental factors ${ }^{12}$. According to World Business Council for Sustainable Development ${ }^{13}$, sustainability refers to the "meeting the needs of the present without compromising the ability of future generations to meet their need". In other words, human beings make an effort to practice their quality of life forward sustainable development not only in present but also for long-term initiatives. Vietnam Gross Domestic Product (GDP) growth rate was around $6.6 \%$, reaching the best performance at $7.08 \%$ in 2018 , top growth performers among ASEAN countries ${ }^{14}$. Vietnam is on the road to integration since the Doi Moi (Renovation) 1986. Chronologically, Vietnam became the Association of Southeast Asian Nations (ASEAN) membership and normalization of United State and Vietnam relations in 1995; 
participated in World Trade Organization (WTO) in 2006; leveraged the Vietnam-Japan Economic Partnership (VJEP) in 2008; signed the Comprehensive and Progressive Agreement for Trans-Pacific Partnership (CPTPP) in 2018; and achieved the EU-Vietnam Free Trade Agreements (EVFTA) in 2019 ${ }^{15}$. Consequently, Vietnam political and economic position has exposed to be praised in the world and Asian community. To meet the demands of partnership, Vietnam is at the turning point and makes an effort to industrialize array of industries by embracing high-tech solutions in agricultural, industrial, and service sectors. The share of agriculture in GDP has been relatively flat since the mid-2000s. In fact, the share of agricultural GDP was around 19\% among other sectors, as compared to Thailand ranging from $10 \%$ to $12 \%{ }^{10}$. Most of the food crop areas in Vietnam are rice (around $70 \%)$, fruit, vegetables, pulses (10\%), maize (5\%), roots and rubbers $(5 \%)$, oil crops, and wheat ${ }^{10}$. The rate of employment in agriculture sector has declined since 2000 . In fact, $70 \%$ of total employment get involved in agriculture sector in 2000 while the decrease labor was at $50 \%$ of total employment in $2013^{10}$. Some Vietnamese agri-food is ranked as top five in exporters in global rank. For example, in terms of total volume, cashews and black pepper are at number one; coffee and cassava are at number two; rice is at number three; rubber and tea share at number four and five, respectively ${ }^{10}$.

By the end of 2018, the agricultural land area in Vietnam was 27,289,454 hectares, which makes up 39.25 percent of Vietnam's total land area ${ }^{16}$. Despite the government has launched numerous policies to encourage land consolidation, land fragmentation negatively affects land profitability and productivity growth. In fact, land fragmentation leads to severe production costs including private costs (e.g., land loss due to boundaries, cumbersome management of infrastructures, increased disputes among neighbors), and public costs (e.g., increasing difficulties in crop and land use planning). In particular, half of 9 million farms in Viet Nam are subsistence farms occupying less than 0.5 hectares ${ }^{17}$. In recent years, the structure of the agricultural sector has shifted toward market demand and adaptation to climate change, which reflected firstly in changing the farm household structure. According to the official results of the Rural, Agricultural and Fishery Census 2016, compared to the year 2011, the number of farm household was 8.58 million, decreased by $8.5 \%$. Furthermore, from 2011 to 2017 , the number of farms in operation throughout Vietnam had a rising trend but was down in 2018 with approximately 31.67 thousand farms. Although there was a slight increase in the number of farms in 2019, this rise was also insignificant. (Figure 1).

In the meanwhile, the number of agricultural cooperatives increases annually, reflecting the bigger development of farmers' scale. For the country as a whole, by the end of 2019, there were approximately 15,414 agricultural cooperatives ${ }^{18}$, which increased by $11.2 \%$ compared to the year 2018 . However, the GDP contribution of agricultural cooperatives in Vietnam gradually decreased from $8.1 \%$ in 2001 to $5.1 \%$ in $2018^{16}$. The main reason for the low contribution is related to ineffective performance. In addition, the linkage between stakeholders in the agricultural sector still remains some constraints. First, the equal market environment has not been enough transparent and conducive for all private, public, and foreign firms ${ }^{10}$. Second, there has been a growing innovative partnership between universities and entrepreneurs with high-tech solutions to bring competitive gains but the success rate is not overwhelming ${ }^{19}$. Third, agricultural policies have not facilitated business services to yield strong domestic private companies ${ }^{17}$. Hence, to achieve a more reinvigorate productivity growth and competitiveness in global agricultural markets, Vietnam must have a better integration of stakeholders into agricultural supply chains by reorganizing and applying blockchain technology.

The Vietnam government proactively has paid attention to high-tech applications and digitalization of economy. As a matter of fact, some crucial policy documents have been released to build the digital economy. For example, Decision No. 392/QĐ-TTg (2015) set targets on information technology development through to 2020 with a vision toward 2025; Decision 16/CT-TTg approved by the Prime Minister to fortify the progress towards Industry $4.0^{20}$. Specifically, the Prime Minister issued the Decree 100/QĐ-TTG, which implements the initiatives in regards to establishing systems for product traceability and provenance in Vietnam since January 2019. Till 2025, at least 30 percent total products would be traced by disruptive technology such as RFID, QR codes, NFC matching with international trading standards in terms of data transactions. These policy documents accordingly prove that the Vietnamese government has devoted a great deal of effort to digitalize the economy in the wake of Industry 4.0 movement.

For product traceability, blockchain plays an important role in the design and implementation of activities related to managing the supply chains. Blockchain refers to a distributed ledger and immutable database for securely exchanging data ${ }^{21}$. 


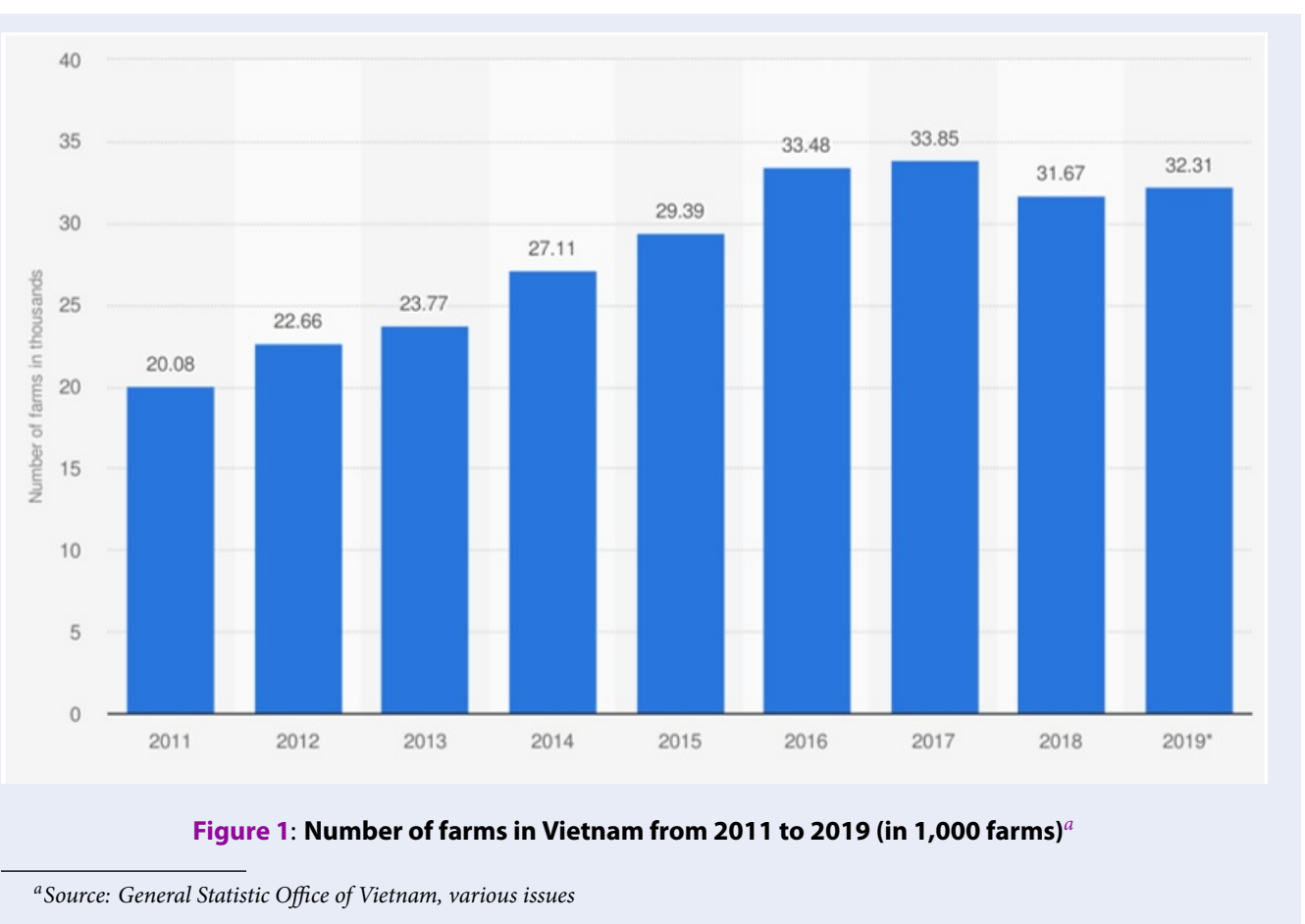

Block regarded as a node contains data for transaction; and cryptographically linking these blocks forms a chain. In other words, blockchain is a distributed peer-to-peer network where nodes can transact without a trusted intermediary ${ }^{22}$. Figure 2 indicates the process of transaction in blockchain ${ }^{23}$. Once a transaction occurs, a distributed ledger is transferred to computer nodes in the P2P network. These nodes encrypt and verify the information of blocks by using a cryptographic algorithm. In the case of consensus agreements among majority of computers, the transaction is valid and the new block of data is added into the chains by the way that the hash in this new block must be the same as the hash in the previous block. If do so, the block of data is time-stamped and impossible to tamper with. Therefore, the notable features of these blocks in the chain are immutable, tamper proof, secure, trust, and transparent ${ }^{21,24}$.

There are three types of blockchains: public, private, and hybrid blockchain network. First, a public or permissionless network means everyone can take part in the verification process without authorization. Computer networks participating in proof of work are often rewarded by cryptocurrency, for example bitcoin, ethereum ${ }^{8}$. In contrast, private or permissioned network requires that verification nodes are known and identified by a central authority or database ${ }^{8}$. Finally, a hybrid network refers to a public permissioned network whose features are somewhere in the middle of the two above. There are numbers of stakeholders getting involved in supply chain so that private blockchain network is preferable to be used. The popular platforms built to this purpose are Hyperledger, Sawtooth, Fabric, Ripe. Io ${ }^{8,9}$.

Blockchain technology fits well with the management of supply chains, particularly in agriculture to monitor the information, financial, and physical flows from farm to fork in terms of traceability. According to Behnke and Marijn, food traceability plays an important role in warranting the food safety and quality, triggering the confidence and satisfaction of consumers $^{25}$. This is because all actors in the supply chain can make the flows of product visible by tracing (backward follow-up) and tracking (forward followup) at any steps.

Figure 3 illustrates the physical flow from providers, producers, processing, distribution, retailers, to consumers combined with digital flow using barcodes, QR codes, NFC, RFID technology, sensors recording data in every step. Blockchain articulates these steps in P2P network ${ }^{9}$. More importantly, all actors take into account smart contracts - "a computerized transaction protocol that executes the terms of a contract" 22 - the verified agreements of all actors in real time. Smart contracts can be not only useful in various industries with moving large food quantities in terms of logistics and inventory but also potential 


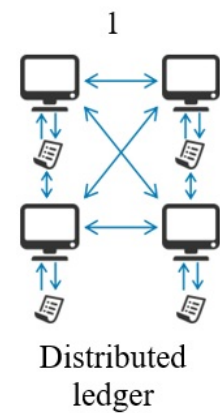

ledger

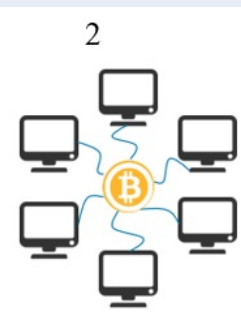

Community validation
3

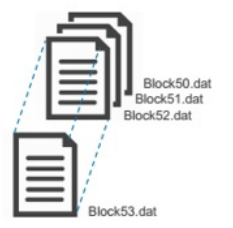

4

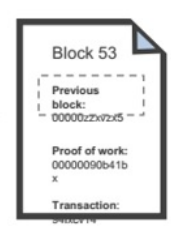

5

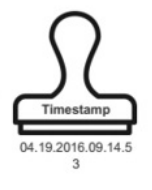

Figure 2: A process of blockchain transaction ${ }^{a}$

${ }^{a}$ Source: Tapscott, 2017

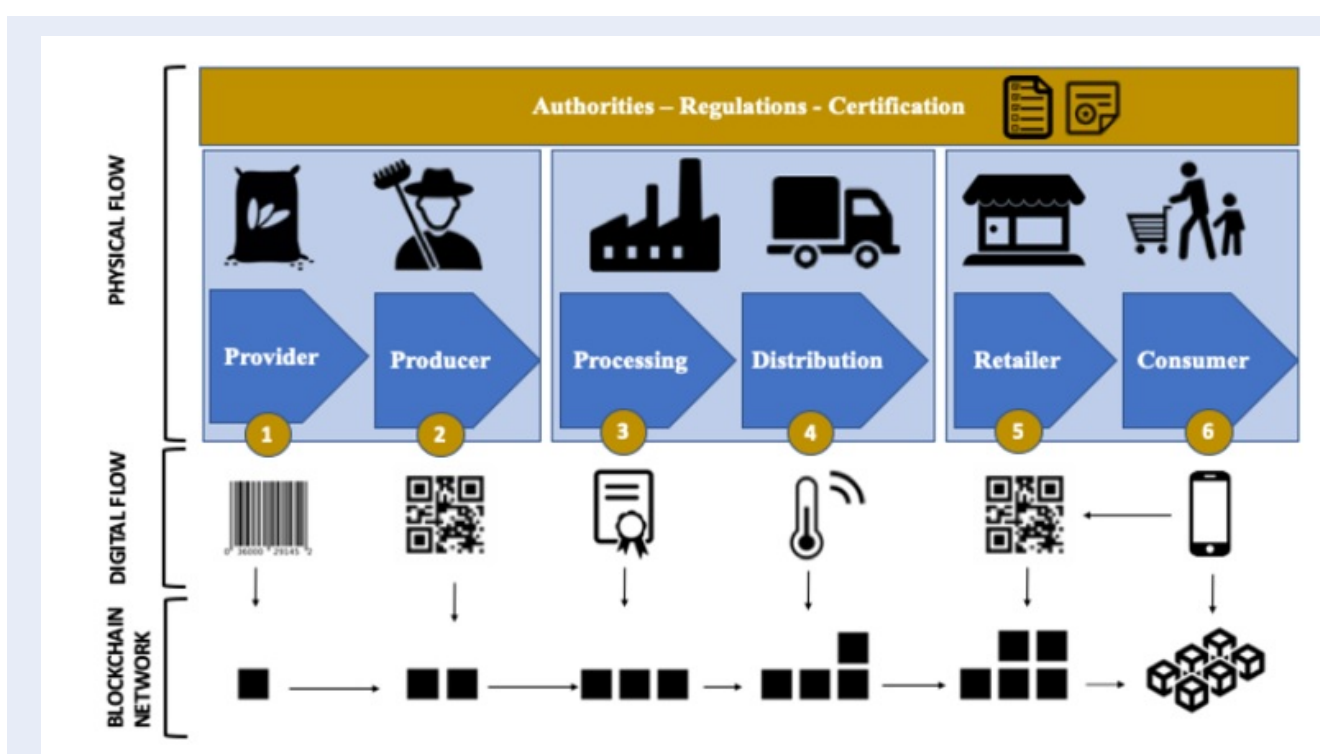

Figure 3: Blockchain technology in agri-food supply chain ${ }^{a}$

${ }^{a}$ Source: Kamilaris et al., 2019

to the growing field of smart agriculture. The earliest known definition for smart contracts provides a better understanding of the relationship between legal and social institutions ${ }^{26}$, in which they refer to secure, machine-readable and executable programs that can automate specified procedure in legal contexts. In particular, based on dynamic clauses and data of a smart agriculture infrastructure, smart contracts formulate negotiations between involved parties $^{27}$. Hence, quality constraints of agricultural supply chain set by the all parties can be met, such as monitoring the quality, size and texture of fruits. According to Helo and Hao, smart contracts support overall quality improvement of supply chains, cost and risk reduction, and trust enhancement ${ }^{8}$. Generally, unlike the traditional supply chain where relationship in pair is established, smart contracts eliminate the information asymmetry in the whole as well as part of supply chain.

Though blockchain technology has emerged in the recent decade and most used for cryptocurrency, there have been a number of blockchain platforms built for supply chain traceability over the globe. In developed countries, some technologies for traceability are well-known such as FarmShare, AgriLedger, Provenance, Arc-Net, Bart.Digital, Bext $360^{9}$, AgriBlock$\mathrm{IoT}^{1}$. Similarly, Vietnamese ICT start-up enterprises 
catch up with the wave of high-tech innovation regarding blockchain applications in agriculture. For example, wowtrace initiative provides the solution of blockchain-enabled traceability in food chains with the notable features of ensuring transparency, enhancing the competitive advantage, gaining the quality of products, and reducing risk ${ }^{11}$. Furthermore, Vietnam Blockchain Corporation, exposing the leading of blockchain technology not only in Vietnam but also in Asia, has offered blockchain-related platform for manufacturing, logistics, finance, agriculture, smart city, and public service provisions ${ }^{28}$. Additionally, TE-Food.vn, a farm-to-table fresh food traceability solution over the globe, did business in using blockchain for food traceability since 2018. Tomochain, a pioneer of blockchain disruptive technology in Vietnam, especially in cryptocurrency ${ }^{29}$.

Though Vietnam ICT enterprises have engaged in digitalization, the rapid pace of the blockchain-based solutions for agriculture seems not to meet the potential growth of agriculture in terms of quantitative and qualitative manner. Because blockchain technology has been applied in some typical agriproduction provinces such as Mekong Delta (i.e., Dong Thap provice) and Central Highland (i.e., Lam Dong) rather than other productive agri-food producers in Vietnam. The mango industry has been one of the five key industries in the Dong Thap province's Agriculture Restructuring Scheme. In fact, Dong Thap province has 9,200 hectares of mango with approximate 100,000 tons annual output; and also exports 93, 000 tons of mangoes to "demanding markets" such as Japan, Australia, South Korea and Russia yearly. However, it remains difficulties to enter the US market. After 10 years of negotiations with VietGap and GlobalGap standards, with blockchain-based traceability technology, Vietnam's first eight tons of mangoes collected from My Xuong Mango Cooperative in Cao Lanh, Dong Thap have reached the US market on April 18, 2020. My Xuong Mango Cooperative cooperated with the VBC to store all essential information involving its fruits on the blockchain to ensure traceability and fight against copycats. Moreover, this project combines with eco-tourism development, where tourists or tourism agency can purchase mangoes in advance through smart contracts. Hence, this facilitate the local economy. Furthermore, as an agricultural hub of the whole country, currently, Lam Dong province has 21 enterprises that have applied blockchain technology to control the supply, food hygiene and traceability for fruit and vegetable such as strawberry, carrot, potato ${ }^{30}$.
Blockchain technology promises to beneficial provisions to create a more sustainable world ${ }^{31,32}$ First, it provides more transparency about the supply chain actors and the reliable provenance across the agrifood supply chains. Second, thanks to smart contracts, there is a limitation of information asymmetry among individual and collective action, hence strengthening the accountability and reducing bureaucracy. Third, it motivates human beings more environmentally friendly behavior. Therefore, this paper aims to analyze the SWOT analysis and benefits and drawbacks of blockchain-based traceability in Vietnam, linking with sustainable development.

\section{RESEARCH METHOD}

The study attempts to analyze the situation of Vietnam agri-food supply chain management. For this purpose, a technique of SWOT (Strengths, Weaknesses Opportunities, and Threats) analysis ${ }^{32}$ has been applied to evaluate the position of agri-food supply chains in Vietnam. The general observations and the review of agri-food supply chains forwarding sustainable agricultural development in Vietnam have motivated this study.

The SWOT analysis is a strategic planning technique, preliminarily used for evaluation of a project or a business venture. SWOT stands for strength, weakness, opportunities, and threats, which are listed in the four quadrants of a $2 \times 2$ grid associated with the favorable and unfavorable internal and external issues respectively. Strengths and weaknesses mention the advantages and disadvantages inside the organization, while opportunities and threats represent the external factors impacting on the organization. On the one hand, the former illustrates the strong points and weak points in terms of human resources, physical resources, financial resources, activities and processes, and experiences; on the other hand, the later describes the future trends in the field we analyze, the economy conditions, funding resources, demographics, physical environment, legislation, and local, national, or internal events.

The SWOT analysis becomes increasingly popular in the academic peer-reviewed literature. Not only does this tool support analyzing and positioning the strategy of the organization, but also it is used for planning purposes. The SWOT analysis has been extended far away from the organization's scope toward the country, and industry ${ }^{33}$.

This paper applies SWOT analysis at the nation-wide scope and agriculture industry to provide analysis and interpretations of different aspects of agri-food supply 
chains in terms of its strengths, weaknesses, opportunities and threats. The corpus of literature reveals that a SWOT analysis has been embraced in the study of short food supply chain system in Europe ${ }^{34}$, sustainable agriculture intensification systems and agricultural extension systems in Africa ${ }^{35}$, resilience of smallholder farmer in Italy ${ }^{36}$. We also found the SWOT analysis for biofuel potential for transportation in Vietnam ${ }^{37}$. However, to our best knowledge, the SWOT analysis for blockchain-based traceability in agri-food supply chains in Vietnam seems to be silent. Therefore, we conduct this research to fill this gap.

We use the case study research method with the archival data from prestigious source of information: (1) peer-reviewed scientific papers (SCOPUS and ISI), (2) white reports (i.e., WorldBank, PwC, FAO) and (3) English-published e-newspapers in Vietnam (i.e., Vietnamnet, VNExpress, SaigonTimes). We use the interpretive technique to conduct this study.

\section{RESEARCH RESULTS AND DISCUSSIONS}

\section{SWOT analysis}

We present a SWOT matrix for blockchain-based supply chains in the Vietnam agriculture sector at the nation-wide scope and agriculture industry in a Table 1.

\section{Strengths}

The strengths of Vietnamese blockchain technologybased agri-food supply chains lie in its huge numbers of high-tech enterprises starting up in this sector. With the technological infrastructure in the mobile network (3G service), blockchain technology is getting more and more sufficient to meet consumers' interests concerning agri-food safety and security. Consumers become more confident in choosing agri-food for their family as well as more loyal to these brands. Blockchain technology could also facilitate the development of the Vietnam farming system based on improving agri-food supply chains by providing transparency and traceability. Simultaneously, it also improves the behaviors of the stakeholders such as their reliability and responsibility.

\section{Weakness}

Despite the enormous strengths inherent in blockchain-based supply chains in Vietnam, its efficacy in contributing to the national agriculture sector still has limited. We are facing difficulties concerning the cost of developing blockchain infrastructure (hardware) and platform (software) because of small farming scale triggers. Additionally, blockchain technology in Vietnam still is at the beginning stage and smallholder farmers have not enough knowledge about it. They have also not been encouraged on adding value to their farm produce by way of quality, processing, packaging, and marketing as well as applying blockchain technology to improve their reputation. That leads to the fact that their products not to be able to compete in the international market. Therefore, scalability is still a big obstacle that they should overcome.

\section{Opportunities}

Opportunities abound for Vietnam to be onward to a place of reckoning in blockchain technology-based agri-food supply chains. These opportunities include high-tech start-ups with the support of government's policies, the IoT devices for blockchain technology with the support of Vietnam 5G service, ICT initiatives with the financial support of foreign investors. Vietnam will be soon one of the fast-growing markets in ICT in the world. Additionally, to export the agri-food products to important markets like the EU, Japan, and the US with the highest quality and food safety requirements, food traceability is obligated $^{38,39}$.

\section{Threats}

The push towards intensifying blockchain technology adoption in the agri-food sector might likely be threatened by the competition from ASEAN countries like Thailand, and the climate change being experienced globally. Vietnam still lags behind Thailand in the application of blockchain in agriculture ${ }^{40}$. One of the main reasons is the lack of information about agri-food products that make it very difficult to compete with Thai products. Agriculture is also likely to be directly affected by climate change such as the drought in Mekong Delta, and rainfall shortage in Central Highland. The effects of urbanization and industrilization on agriculture might likely be made more pronounced as a result of decreasing labor forces in the agricultural sector. Furthermore, there are some difficulties in retrieving information on suppliers and lacking a common language of business in blockchain-based traceability

\section{Sustainable development}

This section proposes the link between the strengths of blockchain technology supply chain abovementioned and sustainable development of agriculture. 
Table 1: The SWOT analysis of blockchain-based supply chains in Vietnam agriculture sector

\begin{abstract}
Strengths
- More than two-thirds (around 60-70\%) of Vietnam agricultural employment participates in the agriculture industry, higher than other ASEAN countries ${ }^{10}$.

- There are exponential growing numbers of high-tech enterprises starting up in the information and communication technology field ${ }^{41}$.

- Blockchain technology drive eco-friendly behaviors in token economy (paperless, less waste and $\mathrm{CO} 2$ emission, ... $)^{8,9}$.

- Smart contracts incentivize the sharing economy, particularly agriculture cooperatives, enhancing overall economic efficiency ${ }^{24}$.

- Blockchain technology leads to trust, transparency, accountability, controlling food safety and security, and therefore producing satisfaction of customers ${ }^{9,21}$.

- The system becomes robust because of fault-tolerance ${ }^{1}$.

- Such exemplary and successful cases as wowtrace and AgriDential solutions stimulate other blockchain platforms to commercialize in Vietnam farming ${ }^{11,28}$.
\end{abstract}

\section{Opportunities}

- Vietnam national government encourages and promotes start-ups in the high-tech industry20.

- Vietnam 5G services - technically supporting the IoT devices that record data for blockchain technology in distributed network, intends to launch in $2020^{46}$.

- Vietnam becomes one of the fast-growing start-ups in the ICT industry in the world ${ }^{47}$.

- EVFTA and US-Vietnam relations pave the way for exporting Vietnamese agri-food products to these markets, which are obligated to food traceability ${ }^{15}$.

- The structure of the Vietnamese population is at golden age. Most are young (under 35 accounting for $60 \%$ of nearly 100 million people), providing a young, abundant, and quality manpower for developing agriculture ${ }^{14}$.

- Foreign investors from developed countries are willing to grant financial sources for ICT initiatives in Vietnam ${ }^{20}$.

- Annual techfest - an innovative technopreneur contest in Vietnam, keeps the momentum of high-tech business ventures going ${ }^{48}$.

- An increasingly Vietnam's agricultural export growth at $142 \%$ from 2008 to $2018^{14}$.

The components of a sustainable food system include three aspects. First, the economic sustainability of a food system illustrates several factors as profit to producers, manufacturers, and retailers and the cost to consumers. Second, the environmental sustainability of a food system refers to land use, waste management, greenhouse gas emissions and biological diversity. Finally, social sustainability of a food system describes food quality, food quantity, food safety, employment, employee welfare, health and

\section{Weaknesses}

- Small and modest farming scale triggers the difficulty of investing IoT devices, and then collects and process data ${ }^{42}$.

- Investment and development of blockchain infrastructure (hardware) and platform (software) for agriculture is quite costly ${ }^{43}$.

- Most smallholder farmers have less understanding of blockchain technology ${ }^{43}$.

- Blockchain technology is till infancy and underconstruction regarding standards for transactions across the world8.

- Blockchain needs a large number of transactions, requiring huge size and bandwidth ${ }^{44}$.

- Linking between the chains of blocks and current ERP system is limited and unsynchronized ${ }^{45}$.

- There is a barrier to scalability ${ }^{24}$.

Threats

- Competitors from ASEAN countries (not only) in blockchain technology adoption, particularly Thailand agriculture $^{49}$.

- Climate changes demotivate farmers to produce and process agri-food (i.e. drought in Mekong Delta, rainfall shortage in Central Highland) ${ }^{50}$.

- Labor forces in agriculture tend to be decreased because urbanization urges them to leave their rural areas and migrate into cities ${ }^{10}$.

- Suppliers do not want to join in the systems to share information $^{45}$.

- There is an absence of regulatory blockchain and a common language of business in blockchain-based traceability ${ }^{51}$.

nutrition ${ }^{52}$. From the viewpoints of three sustainable dimensions, we synthesize the nexus between the blockchain-based applications and food system sustainability in Table 2, that today food system benefits from the blockchain traceability systems.

\section{CONCLUSION AND POLICY IMPLICATIONS}

This study is significantly important to provide the SWOT analysis of blockchain-based supply chains 
Table 2: Blockchain-based supply chain for agriculture and sustainability

\begin{tabular}{|c|c|c|}
\hline Economic impacts (Profits) & Environmental impacts (Planet) & Social impacts (People) \\
\hline $\begin{array}{l}\text { - Exclusion on third-party agents } \\
\text { or intermediaries among supply } \\
\text { chain partnership }{ }^{24} \text {. } \\
\text { - Encouragement in sharing econ- } \\
\text { omy models such as agriculture } \\
\text { cooperatives }{ }^{53} \text {. } \\
\text { - Reduction in transactional } \\
\text { cost }^{8,24} \text {. } \\
\text { - Stimulation on the development } \\
\text { of short food supply chains }{ }^{9} \text {. } \\
\text { - Development the novel busi- } \\
\text { ness model of food-tourism } \\
\text { that involved agriculture with } \\
\text { tourism }{ }^{28} \text {. } \\
\text { - Setting up the efficient price } \\
\text { in markets because information } \\
\text { asymmetries are eliminated } \\
\text { among stakeholders }{ }^{54} \text {. } \\
\text { - High efficiency of internal } \\
\text { operation procedures }{ }^{8} \text {. }\end{array}$ & $\begin{array}{l}\text { - Reduction in } \mathrm{CO} 2 \text { emission due to mis- } \\
\text { taken routing or under-optimized trans- } \\
\text { portation problems }{ }^{55} \text {. } \\
\text { - Avoidance of paper-based documents } \\
\text { about procedures among partners for } \\
\text { agreement }{ }^{55} \text {. } \\
\text { - Reduction in energy consumption } \\
\text { (turn-off or hibernate IoT devices in the } \\
\text { internal of data transmission or token } \\
\text { used) }{ }^{56} \text {. }\end{array}$ & $\begin{array}{l}\text { - Elimination of fertilizer and chemi- } \\
\text { cal substances remained in food prod- } \\
\text { ucts }^{43} \text {. } \\
\text { - Minimization on contaminated food } \\
\text { scandals }^{57} \text {. } \\
\text { - Compliance with the HACPP and Vi- } \\
\text { etGap }^{58} \text {. } \\
\text { Improvement in customer satisfaction: } \\
\text { - Food safety and security }{ }^{57} \text {. } \\
\text { - Enhancement in collaboration and } \\
\text { cooperation }{ }^{43} \text {. } \\
\text { - Trust and transparency } \\
\text { Support local agri-business }\end{array}$ \\
\hline
\end{tabular}

for agriculture in Vietnam and the links between the strengths of blockchains applied for supply chains and the sustainable development. It is a preliminary stage for both local and national authorities to devise holistic strategic planning of the agriculture industry in tandem with the evolution of advanced technology. The agriculture sector and high-tech application seem to move at an accelerating pace but different paces. Therefore, it is ultimately necessary to have a master plan regarding the convergence agriculture and IT industry for the purpose of improving the efficiency, effectiveness, and sustainability in the agriculture sector.

It seems that blockchain is a promising technology towards a transparent supply chain of various agricultural products; however, there are still many barriers and challenges to hinder its wider popularity among farmers and systems in Vietnam. Hence, it is important to prescribe some policies for blockchain food traceability in the context of Vietnam agriculture sector.

First, blockchain technology applied in agriculture is more developed in Southern regions, particularly in Mekong Delta and Highland areas, while the adoption of IoT devices is more popular in the Northern regions. However, the use of blockchain technology goes without IoT devices. Therefore, both inclusively support each other in the disruptive technology applied in agriculture.
Second, blockchain traceability has been widely executed for various types of products such as mango, lychee, dragon fruits, durian. It had better apply this disruptive technology not only in farming but also in the livestock industry.

Third, we suggest the business model of cooperatives aiming to sharing economy. Hence, the cooperatives do business by planning and organizing eco-tourism services in the harvesting seasons. Such the project of "my mango garden" at My Xuyen - Dong Thap province, there has been a cooperative selling mangos for tourists or tourism agency in advance.

Fourth, we suggest developing more qualified IT developers in blockchain technology in the same manners as Artificial Intelligence, Big Data, and IoT; consequently, developing an ecosystem of blockchain technology surrounds advanced technology in Vietnamese agriculture.

Finally, a number of important limitations need to be considered. First, we adopted the desk research method, so that it cannot avoid the biased perspective made by authors. For the robustness and more insight, we expect to conduct in-depth interviews with stakeholders (i.e., blockchain platform developers, farmers, local authorities) involving in developing and using blockchain relevant to agri-food supply chain in Vietnam. Second, we approach the research from the management viewpoints, so that future research expects to reveal more technical issues. 
Both management and technical viewpoints can provide with a holistic view about thi s research topic. Thirdly, some case studies of blockchain application namely Agridential, which have been succeeded in practices such as My Xuyen project, still are silent in academia. Therefore, we attempt to unveil these typical cases get published scholarly.

\section{ABBREVIATION}

ASEAN: Association of Southeast Asian Nations.

ERP: Enterprise Resource Planning

EVFTA: EU-Vietnam Free Trade Agreement

FAO: Food and Agriculture Organization

GDP: Gross Domestic Product

HACCP: Hazard Analysis and Critical Control Point

ICT: Information and Communication Technology

IoT: Internet of Thing

IT: Infomration Technology

NFC: Near-Field Communications

QR: Quick Response

RFID: Radio Frequency Identification

SCM: Supply Chain Management

SDGs: Sustainable Development Goals

SWOT: Strength, Weakness, Opportunities, and Threats.

VietGAP: Vietnam Good Agricultural Practice UN: United Nation

\section{CONFLICTS OF INTEREST}

The authors have no conflicts of interest to declare. All co-authors have seen and agree with the contents of the manuscript and final version of the paper, there is no financial interest to report.

\section{AUTHOR CONTRIBUTIONS}

Both Tran Thien Vu and Trinh Hoang Hong Hue contributed to the design and implementation of the research, to the analysis of the results and discussions, and to the writing of the manuscript. Tran Thien Vu is a corresponding author.

\section{REFERENCES}

1. Caro MP, Ali MS, Vecchio M, Giaffreda R. Blockchain-based traceability in Agri-Food supply chain management: A practical implementation. 2018 loT Vertical and Topical Summit on Agriculture, 2018; Tuscany, Italy: IEEE. 2018;p. 1-4.

2. Hobbs JE. Information asymmetry and the role of traceability systems. Agribusiness. 2004;20(4):397-415. Available from: https://doi.org/10.1002/agr.20020.

3. McCluskey JJ. A Game Theoretic Approach to Organic Foods: An Analysis of Asymmetric Information and Policy. Agricultural and Resource Economics. 2000;29(1):1-9. Available from: https://doi.org/10.1017/S1068280500001386.

4. Elbasha EH, Riggs TL. The effects of information on producer and consumer incentives to undertake food safety efforts: a theoretical model and policy implications. Agribusiness: An International Journal. 2003;13:29-42. Available from: https: //doi.org/10.1002/agr.10043.
5. Starbird SA, Amanor-Boadu A. Contract selectivity, food safety, and traceability. Journal of Agricultural \& Food Industrial Organization. 2007;5(1):1-22. Available from: https://doi. org/10.2202/1542-0485.1141.

6. World Bank. Vietnam food safety risks management: Challenges and Opportunities. Technical Working Paper. Hanoi, Vietnam: World Bank. 2017;

7. Cole R, Steveson M, Aitken J. Blockchain technology: implications for operations and supply chain management. Supply Chain Management. 2019;24(4):469-483. Available from: https://doi.org/10.1108/SCM-09-2018-0309.

8. Helo P, Hao Y. Computers \& Industrial Engineering Blockchains in operations and supply chains: A model and reference implementation. Computers \& Industrial Engineering. 2019;136:242-251. Available from: https://doi.org/10.1016/j.cie.2019.07.023.

9. Kamilaris A, Fonts A, Boldv́ FXP. The Rise of Blockchain Technology in Agriculture and Food Supply Chains. Trends in Food Science \& Technology. 2019;91:640-652. Available from: https://doi.org/10.1016/j.tifs.2019.07.034.

10. World Bank. Transforming Vietnamese Agriculture: Gaining More from Less. Vietnam Development Report. Hanoi: Hong Duc Publishing House. 2016;.

11. Wowtrace. Wowtrace changes the industry of provenance. [Online] [truy cập ngày 03/12/2020];Available from: https:// www.wowtrace.io/tinh-nang/.

12. United Nations. Transforming our world: The 2030 agenda for sustainable development. The United Nations General Assembly. 2015;

13. World Business Council for Sustainable Development. The business case for sustainable development. 2002;Available from: http://www.wbcsd.org/web/publications/business-case. pdf.

14. PwC. Doing Business in Vietnam: A Reference guide for entering the Vietnam Nam market. PwC Vietnam. 2019;Available from: https://www.pwc.com/vn/en/publications/vietnampublications.html.

15. PwC. Free Trade Agreement signed with European Union. PwC Vietnam. 2019;Available from: https://www.pwc.com/vn/en/ publications/news-brief/190701-evfta.html.

16. Vietnam Cooperative Alliance. Annual Report 2019. 2019;Available from: http://vca.org.vn/en/annual-report2019-a122.html.

17. OECD. Multi-dimensional Review of Viet Nam: Towards an Integrated, Transparent and Sustainable Economy. OECD Development Pathways. Paris: OECD Publishing. 2020;.

18. Ministry of Agriculture and Rural Development. Annual Statistic Report. 2020;Available from: https://www.mard.gov.vn/ Pages/bao-cao-thong-ke.aspx.

19. Australian Trade and Investment Commission. Vietnam's Innovation Ecosystem 2019. Australia Unlimited Publishing. 2019;

20. Cameron A, Pham T, Atherton J. Vietnam Today - first report of the Vietnam's Future Digital Economy Project. CSIRO: Brisbane. 2018;;

21. Maslova N. Blockchain: Disruption and Opportunities. Strategic Finance. 2018;7:24-29.

22. Christidis K, Member GS. Blockchains and Smart Contracts for the Internet of Things. IEEE Access. 2016;4:2292-2303. Available from: https://doi.org/10.1109/ACCESS.2016.2566339.

23. Tapscott A. Blockchain revolution: Surviving and Thriving in the 2nd era of the internet. Tapscott Corporation. 2016.;

24. Underwood S. Blockchain Beyond Bitcoin. Communications of the ACM. 2016;59(11):15-17. Available from: https://doi. org/10.1145/2994581.

25. Behnke K, Marijn MFWHAJ. Boundary conditions for traceability in food supply chains using blockchain technology. International Journal of Information Management. 2019;52:101969. Available from: https: //doi.org/10.1016/j.ijinfomgt.2019.05.025.

26. Szabo N. The idea of smart contracts. Nick Szabos Papers and Concise Tutorials. 1997;p. 6. 
27. Voutos Y, Drakopoulos G, Mylonas M. Smart Agriculture: An Open Field For Smart Contracts. SEEDA conference at Piraeus, Hellas: Greece. 2019;Available from: https://doi.org/10.1109/ SEEDA-CECNSM.2019.8908411.

28. Vietnam Blockchain Corporation. Infinity Blockchain Solutions for daily life. 2020;Available from: https: //vietnamblockchain.asia/vi/.

29. Vietnamnet. Tomochain CEO: The messenger of blockchain. 2019;Available from: https://english.vietnamnet.vn/fms/ science-it/218921/tomochain-ceo-- the-messenger-ofblockchain.html.

30. Chamber of Commerce and Industry of Vietnam. Lam Dong Can Khoi Thong Nguon Von Cho San Xuat Nong Nghiep Cong Nghe Cao. 2020;Available from: https://www.vcci.com.vn/lam-dong-can-khoi-thong-nguonvon-cho-san-xuat-nong-nghiep-cong-nghe-cao.

31. Song XW, Merveille N. Research on Blockchain for Sustainable E-Agriculture. 2020 IEEE Technology \& Engineering Management Conference. Miami:USA. 2020;Available from: https: //doi.org/10.1109/TEMSCON47658.2020.9140121.

32. Hill T, Westbrook R. SWOT Analysis: It's time for a product recall. Long Range Planning. 1997;30(1):46-52. Available from: https://doi.org/10.1016/S0024-6301(96)00095-7.

33. Helms MM, Nixon J. Exploring SWOT Analysis - Where Are We Now? A Review of Academic Research from the Last Decade. Journal of Strategy and Management. 2010;3(3):215-251. Available from: https://doi.org/10.1108/17554251011064837.

34. Casolani N. Sustainability of Short Food Supply Chain System in Europe: A SWOT Analysis. Global \& Local Economic Review. 2015;19(2).

35. Mutenje $M$, Ghimire $S$, Wosten $H$, Bloem E, Mutimura $M$, Dechassa N, Moeletsi ME et al. An Overview and SWOT Analyses of Sustainable Agriculture Intensification Systems and Agricultural Extension Systems. Horizon 2020 European Union Report. 2018;(727201)

36. Rocha RR. Resilience of Smallholder farmers: A SWOT Analysis in Rural Italy. The 13th European IFSA Symposium, Chania, Greece. 2018;;

37. Trinh TA, Le TPL. Biofuels Potential for Transportation Fuels in Vietnam: A Status Quo and SWOT Analysis. IOP Conference Series: Earth Environment Science. 2018;143:01265. Available from: https://doi.org/10.1088/1755-1315/143/1/012065.

38. Mania I, Delgado A, Barone C, Parisi S. Food Traceability System in Europe: Basic and Regulatory Requirements: Theory and Practice. In book: Traceability in the Dairy Industry in Europe. 2018;Available from: https://doi.org/10.1007/978-3-03000446-0.

39. Sue Zach L. Legal Requirements and Regulation for Food Traceability in the United States. In book: Advances in Food Traceability Techniques and Technologies. 2016 ;Available from: https://doi.org/10.1016/B978-0-08-100310-7.00013-2.

40. Vietnamnet. Vietnam lags behind Thailand in use of blockchain in agriculture.2018;Available from: https: //english.vietnamnet.vn/fms/science-it/200262/vietnam-lagsbehind-thailand-in-use-of-blockchain-in-agriculture.html.

41. VNExpress. Vietnam Startup Investment beats Singapore. 2020;Available from: https://e.vnexpress.net/news/business/ data-speaks/vietnam-startup-investment-beats-singapore4053625.html.

42. Antony AP, Leith K, Jolley C, Lu J, Sweeney DJ. A Review of Practice and Implementation of the Internet of Things for
Smallholder Agriculture. Sustainability. 2020;12:37-50. Available from: https://doi.org/10.3390/su12093750.

43. Sylvester G. E-Agriculture in Action: Blockchain for Agriculture Opportunities and Challenges. Food and Agriculture Organization of the United Nations and the International Telecommunication Union, Bangkok. 2019;

44. Yli-Huumo J, Ko D, Choi S, Park S, Smolander K. Where Is Current Research on Blockchain Technology? A Systematic Review. PLoS ONE. 2016;11(10):e0163477. PMID: 27695049. Available from: https://doi.org/10.1371/journal.pone.0163477.

45. Gaur V, Gaiha A. Building a Transparent Supply Chain. Harvard Business Review. 2020;

46. Dharmaraj S. Vietnam to Commercialize $5 \mathrm{G}$ in October 2020. OpenGov. 2020;Available from: https://opengovasia com/vietnam-to-commercialise-5g-in-october-2020/.

47. Nhandan. Vietnam becomes one of hottest hubs in the world 2019;Available from: https://en.nhandan.org.vn/scitech/item/ 7589202-vietnam-becomes-one-of-hottest-startup-hubs-inthe-world-ibtimes.html.

48. Techfest. Startup World Cup Continuously Associated with Techfest Vietnam 2019: A Dynamic Opportunity for Start-up Vietnam. 2020;Available from: https://techfest.vn/en/news/startup-world-cup-continuouslyassociated-with-techfest-viet-nam-2019-a-dynamicopportunity-for-startup-viet-nam.

49. Vietnamnet. Vietnam Lags Behind Thailand in Use of Blockchain in Agriculture. 2018;Available from: http: //english.vietnamnet.vn/fms/science-it/200262/vietnam-lagsbehind-thailand-in-use-of-blockchain-in-agriculture.html.

50. Food and Agriculture Organization. FAO Rapidly Responds to Severe Drought in Vietnam. 2016;Available from: http://www. fao.org/vietnam/news/detail-events/en/c/416018/.

51. GS1. Bridging Blockchains: Interoperability is Essential to the Future of Data Sharing. GS1 US. 2018.;

52. Swanson KS, Carter RA, Yount TP, Aretz J, Buff PR. Nutritional Sustainability of Pet Foods. Advances in Nutrition. 2013;4(2):141-150. PMID: 23493530. Available from: https: //doi.org/10.3945/an.112.003335.

53. Filippi PD. What Blockchain Means for the Sharing Economy Harvard Business Review. 2017;

54. Zavolokina L, Schlegel M, Schwabe G. How can we reduce information asymmetries and enhance trust in 'The Market for Lemons'? Information System E-Business Management. 2019;Available from: https://doi.org/10.1007/s10257020-00466-4.

55. Casino F, Dasaklis TK, Patsakis C. A Systematic Liturature Review of Blockchain-based Applications: Current Status, Classification and Open Issues. Telematics and Informatics. 2018;36:55-81. Available from: https://doi.org/10.1016/j.tele. 2018.11.006.

56. Schletz M, Cardoso A, Dias GP, Salomo S. How Can Blockchain Technology Accelerate Energy Efficiency Interventions? A Use Case Comparison. 2020;13(22):58-69. Available from: https: //doi.org/10.3390/en13225869.

57. Iftekhar A, Cui X, Hassan M, Afzal W. Application of Blockchain and Internet of Things to Ensure Tamper-Proof Data Availability for Food Safety. Journal of Food Quality. 2020;Available from: https://doi.org/10.2139/ssrn.3615496.

58. SaigonTimes. Blockchain can help ensure food safety. 2018;Available from: https://english.thesaigontimes.vn/61114/ blockchain-can-help-ensure-food-safety.html. 


\title{
Ứng dụng công nghệ blockchain cho chuỗi cung ứng nông sản theo hướng bền vững ở Việt Nam: phân tích SWOT
}

\author{
Trần Thiện Vũ ${ }^{1, *}$, Trịnh Hoàng Hồng Huệ ${ }^{2}$
}

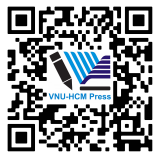

Use your smartphone to scan this QR code and download this article

${ }^{1}$ Trường Đại học Công nghệ Thông tin và Truyên thông Việt-Hàn, Đại học Đà Năng, Việt Nam

${ }^{2}$ Trương Đại học Kinh tế - Luật, ĐHQG HCM, Việt Nam

Liên hệ

Trần Thiện Vũ, Trường Đại học Công nghệ Thông tin và Truyền thông Việt-Hàn, Đại học Đà Nắng, Việt Nam

Email: ttvu@vku.udn.vn

Lịch sử

- Ngày nhận: 28/07/2020

- Ngày chấp nhận: 21/12/2020

- Ngày đăng: 13/2/2021

DOI : 10.32508/stdjelm.v5i1.675

\section{Check for updates}

\section{Bản quyền}

๑ ĐHQG Tp.HCM. Đây là bài báo công bố mở được phát hành theo các điều khoản của the Creative Commons Attribution 4.0 International license.

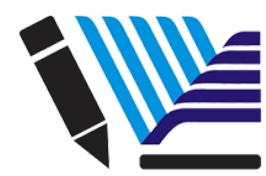

VNU-HCM Press

\section{TÓM TẮT}

Ngày nay, những công nghệ đột phá như nền tảng chuỗi khối có tiềm năng trong việc đóng góp giá trị gia tăng cho những ứng dụng cho đa dạng các ngành khác nhau. Công nghể blockchain, được xem như là thế hệ thứ hai của Internet trong thời đại số, đã được ứng dụng rộng rãi trong thực tiễn cho nhiều ngành như tài chính, sức khỏe, du lịch, bán lẻ, sản xuất - chế tạo, giáo dục, lĩnh vực công, quản lý chuỗi cung ứng, sản phẩm nông nghiệp và nhiều ngành nghể khác. Trong đó, việc vận hành chuỗi cung ứng cho sản phẩm nông nghiệp dựa trên công nghệ chuỗi khối có tiềm nắng phát triển và hữu ích cho ngành nông nghiệp. Trong bối cảnh khu vực, Việt Nam là quốc đa đạt nhiều lợi thế cạnh tranh trong sản xuất nông sản trên thế giới như hạt tiêu, hạt điều, cà phê, dừa, gạo, và cao su. Hơn nữa, trong khu vực các nước ASEAN, Việt Nam là một trong những quốc gia tiên phong trong việc áp dụng công nghệ chuỗi khối để truy xuất nguồn gốc nông sản. Tuy nhiên, việc thiết kế và thực thi ứng dụng công nghệ chuỗi khối trong sản xuất nông nghiệp trong bối cảnh của ngành nông nghiệp Viêt Nam gặp nhứng cơ hội và thách thức, bên cạnh thế mạnh và điểm yếu của ngành. Bài báo này tập trung phân tích điểm mạnh, điểm yếu, cơ hội, và thách thức cho việc quản trị chuỗi cung ứng nông sản dựa trên nền tảng chuỗi khối. Đồng thời, ứng dụng công nghệ chuỗi khối có thể thúc đẩy phát triển nông nghiệp bền vững, hướng đến Mục tiều Phát triển Bền vững của Liên hợp quốc trong thế kỷ 21. Chúng tôi sử dụng phương pháp tiếp cận diễn giải trong việc khảo cứu và tổng hợp các tài liệu nghiên cứu, và diền dịch các kết quả nghiên cứu. Cuối cùng chúng tôi đề xuất những khuyến nghị và hàm ý chính sách cho giới hữu quan như các nhà làm chính sách, tổ chức thiết kế và phát triển công nghệ chuỗi khối, các người dùng là nông dân, trong việc thúc đẩy triển khai chuỗi nông sản trên nền tảng chuỗi khối trong bối cảnh ngành nông nghiệp Việt Nam.

Từ khoá: Công nghệ chuỗi khối, quản lý chuỗi cung ứng, bền vững, nông nghiệp Việt Nam, phân tích SWOT
Trích dẫn bài báo này: Vũ T T, Huệ T H H. Ứng dụng công nghệ blockchain cho chuỗi cung ứng nông sản theo hướng bền vững ở Việt Nam: phân tích SWOT. Sci. Tech. Dev. J. - Eco. Law Manag.; 5(1):1278-1289. 